\title{
Serum Vitamin D Level in Type 2 Diabetic Subjects: Relation to Glycemic Control, Insulin Resistance and Proinflammatory Markers
}

\author{
Talaat A. Abdel Aaty ${ }^{1}$, Magdy H.Z. Magallaa ${ }^{1}$, Hend Abdel Moneim $^{1 ¥}$, Hanaa M. Ismail ${ }^{2}$, \\ Doaa M. Genena ${ }^{3}$, Riham Frugina ${ }^{1}$ \\ ${ }^{1}$ Department of Internal Medicine, Faculty of Medicine, Alexandria University, Egypt. \\ ${ }^{2}$ Department of Nutrition, High Institute of Public Health, Alexandria University, Egypt. \\ ${ }^{3}$ Medical Research Institute, Alexandria University, Egypt.
}

\begin{abstract}
Background: Type 2 diabetes mellitus (DM) is one of the most common diseases worldwide. Early diagnosis and management has a significant role in reducing complications. Vitamin $D$ is a fat-soluble vitamin that showed important functions regarding calcium and phosphate homeostasis, immunity and insulin resistance. There is a well-established link between vitamin D level and type $2 \mathrm{DM}$.

Objective(s): The aim of this study was to assess serum $25(\mathrm{OH})$ vitamin $\mathrm{D}_{3}$ level in type 2 diabetic subjects and to investigate its relation to glycemic control, proinflammatory markers and insulin resistance.

Methods: The study included 60 type 2 diabetic subjects in the age group 40-70 years and 30 controls matched for age and gender. Pregnant females, renal, hepatic and cancer patients were excluded from the study. All participants were subjected to detailed history taking, anthropometric measurements including weight, height and waist circumference, full clinical examination and laboratory investigations including serum $25(\mathrm{OH})$ vitamin $\mathrm{D}_{3}, \mathrm{FSG}, \mathrm{HbA}_{1} \mathrm{c}$, serum insulin, and CRP.HOMA-IR was calculated using FSG and serum insulin values.

Results: The mean serum concentration of $25(\mathrm{OH})$ vitamin D3 was significantly lower in type 2 diabetics compared to controls $(2.91 \pm 4.20 \mathrm{ng} / \mathrm{ml}, 12.04 \pm 7.74$ respectively) $(p<0.001)$. There was a significant increase in BMI, WC, FSG, HbA1c, serum insulin, and HOMA-IR in type 2 diabetics compared to controls $(p<0.05)$. A statistical significant negative correlation was found between $25(\mathrm{OH})$ vitamin $\mathrm{D} 3$ level and the following parameters: BMI ( $\mathrm{r}=-0.584, p<0.001)$, WC $(\mathrm{r}=-0.233, p=0.027)$, FSG $(\mathrm{r}=-0.735, p<0.001), \mathrm{HbA1C}(\mathrm{r}=-0.387$, $p<0.001)$, HOMA-IR $(\mathrm{r}=-0.729, p<0.001)$, serum insulin $(\mathrm{r}=-0.272, p=0.010)$. Meanwhile, 25(OH) vitamin D3 did not significantly correlate with the proinflammatory marker CRP $(\mathrm{r}=-0.126, p=0.238)$.

Conclusion Subjects with type $2 \mathrm{DM}$ have low $25(\mathrm{OH})$ vitamin $\mathrm{D}_{3}$ level compared to healthy normal individuals. The negative association of $25(\mathrm{OH})$ vitamin $\mathrm{D} 3$ with glycemic control and its irrelevance to the proinflammatory markers suggest that vitamin D may be an important determinant in the pathogenesis of type 2 DM. Hence, cautious Vitamin D supplementation may have a therapeutic potential in prevention and management of Type 2 DM.
\end{abstract}

Key word: Type 2 DM, glycemic control, vitamin D, proinflammatory markers, CRP, insulin resistance.

\section{INTRODUCTION}

$\mathrm{D}$ iabetes mellitus (DM) is a chronic multi-systemic multi-etiological illness characterized by chronic hyperglycaemia with abnormal carbohydrate, fat, and protein metabolism. ${ }^{(1)}$ Rates of type $2 \mathrm{DM}$ are increasing worldwide. (2) The etiology of type 2 DM appears to involve complex interactions between environmental and genetic factors. ${ }^{(3)}$ The American Diabetes Association (ADA) criteria for the diagnosis of diabetes are any of the following: Glycated hemoglobin (HbA1c) level of $6.5 \%$ or higher, A fasting serum glucose
Available on line at:

www.jhiph.alexu.edu.eg

$¥$ Correspondence:

Email:

hendhasan2012@hotmail.com

Suggested Citations: Abdel Aaty TA, Magallaa MHZ, Moneim H, Ismail HM, Genena DM, Frugina R. Serum vitamin D level in type 2 diabetic subjects: Relation to glycemic control, insulin resistance and proinflammatory markers. JHIPH. 2017;47(2):6268.
(FSG) level of $126 \mathrm{mg} / \mathrm{dL}$ or higher, a 2-hour serum glucose level of $200 \mathrm{mg} / \mathrm{dL}$ or higher, a random serum glucose of $200 \mathrm{mg} / \mathrm{dL}$ or higher. ${ }^{(4)}$ Vitamin D is a fatsoluble vitamin that is important for calcium homeostasis and for optimal skeletal health. The major function of vitamin D is to increase the efficiency of calcium absorption from the small intestine. ${ }^{(5)}$ Vitamin D, as either D2 or D3, does not have significant biological activity. Rather, it must be metabolized within the body to the hormonally-active form known as 1,25dihydroxycholecalciferol which is done by the liver and the kidney. ${ }^{(6)}$ Vitamin D was also found to play an important 
role in immune system ${ }^{(7,8)}$, inhibits the growth of cancer cells $^{(9,10)}$, and plays a significant role in insulin resistance. ${ }^{(11-14)}$ More recently, there is accumulating evidence to suggest that altered vitamin $\mathrm{D}$ and calcium homeostasis may also play a role in the development of type $2 \mathrm{DM}^{(15)}$ Therefore, the aim of this study was to assess serum $25(\mathrm{OH})$ vitamin D3 level in type 2 diabetic subjects and to study its relation to glycemic control, proinflammatory markers and insulin resistance.

\section{METHODS}

Study setting, Design and Participants: This case control study was performed in Alexandria university students' hospital in the period from September 2014 to August 2015.The study included 90 participants of both sexes aged 40-60 years; i) group I comprised 60 type 2 diabetic subjects (21 males and 39 females) diagnosed since at least 6 months, and ii) group II that included 30 healthy subjects ( 8 males and 22 females) matched for age and gender and served as a control group. Pregnant females renal, hepatic, parathyroid, and cancer patients, as well as subjects on vitamin D supplementation and those with abnormal serum calcium level were excluded from the study. All participants were subjected to detailed history taking with a special focus on the duration of diabetes, smoking and its duration, medical history and history of diabetic complications. Full clinical examination was done, including neurological examination and detection of diabetic complications.

Anthropometric assessment: Measurements of weight, height, waist circumference was done according to criteria described by Gibson (2005). ${ }^{(16)}$ An increased waist circumference $(\geq 35$ in $[88 \mathrm{~cm}]$ for women, $\geq 40$ in [103 cm] for men) defines excess abdominal adiposity according to the Adult treatment program III criteria. ${ }^{(17)}$ Body mass index (BMI) was calculated according to the formula (weight) in $\mathrm{Kg}$ / (height) ${ }^{2}$ in meters.

laboratory investigations: Following 12 hours of fasting, $5 \mathrm{ml}$ of whole blood was drawn from each participant. One ml of blood was added to Ethylene Diamine Tetra Acetic Acid (EDTA) to perform HbA1C assay. ${ }^{(18)}$ The remaining $4 \mathrm{ml}$ of the sample was left to clot and was centrifuged. Sera were separated and were used to measure the concentration of fasting serum glucose (FSG) using colorimetric analysis. ${ }^{(19)}$ Serum $25(\mathrm{OH})$ vitamin D3 levels were measured using high performance liquid chromatography (HPLC). ${ }^{(20,21)}$ Serum insulin levels were determined using enzyme linked immunosorbent assay (ELISA). ${ }^{(22)}$ Insulin resistance was evaluated by homeostasis model assessment of insulin resistance (HOMA-IR) using the following equation: HOMA-IR= Fasting serum glucose $(\mathrm{mmol} / \mathrm{L}) \times$ Serum insulin $(\mu \mathrm{U} / \mathrm{mL}) .^{(23)}$ C-reactive protein (CRP) was measured by the immunoturbidimetry method. ${ }^{(24,25)}$

\section{Statistical Analysis}

Data were analyzed using IBM SPSS software package version 20.0. Qualitative data were described using number and percent. Quantitative data were described using range (minimum and maximum), mean and standard deviation. Student's t test and Mann Whitney test were used to evaluate the significance of the difference between means. Spearman coefficient was used to correlate between two abnormally quantitative variables. Significance of the obtained results was judged at the $5 \%$ level. ${ }^{(26)}$

\section{Ethical Considerations}

This study was conducted according to the guidelines laid down for medical research involving human subjects and was approved by the ethics committee of the faculty of medicine, Alexandria University, Egypt. All measurements were taken in full privacy and the collected data were kept confidential. All participants were informed about the objective of the study and that they had the right to accept or refuse to participate in the study, then their written consent was obtained.

\section{RESULTS}

Ninety Egyptian adults of both sexes were included in this study. In group I (diabetic subjects) 21 males and 39 females which did not differ significantly from that of group II (controls; 8 males and 22 females) $(p=0.425)$. The mean \pm SD ages (Subjects: $55.97 \pm 8.63$ years; controls: $54.27 \pm 10.13$ years) were not significantly different between the two groups $(p=0.408)$ (Table 1). Concerning the anthropometric measures of the participants, table (2) shows that BMI and WC was significantly higher in diabetics $(32.33 \pm 4.92 \mathrm{~kg} / \mathrm{m} 2$, $104.70 \pm 8.94 \mathrm{~cm}$ respectively) as compared to controls $(27.21 \pm 4.42 \mathrm{~kg} / \mathrm{m} 2,98.13 \pm 9.99 \mathrm{~cm}$ respectively).

Table (1): Comparison between the two studied groups according to their demographic data

\begin{tabular}{|c|c|c|c|c|c|c|}
\hline & \multicolumn{2}{|c|}{$\begin{array}{c}\text { Subjects } \\
(n=60)\end{array}$} & \multicolumn{2}{|c|}{$\begin{array}{c}\text { Control } \\
(n=30)\end{array}$} & \multirow[t]{2}{*}{ Test of sig. } & \multirow[t]{2}{*}{$p$} \\
\hline & No. & $\%$ & No. & $\%$ & & \\
\hline \multicolumn{7}{|l|}{ Sex } \\
\hline Male & 21 & 35.0 & 8 & 26.7 & \multirow[b]{2}{*}{$\chi^{2}=0.636$} & \multirow{2}{*}{0.425} \\
\hline Female & 39 & 65.0 & 22 & 73.3 & & \\
\hline \multicolumn{7}{|l|}{ Age (years) } \\
\hline Min. - Max. & \multicolumn{2}{|c|}{$40.0-70.0$} & \multicolumn{2}{|c|}{$40.0-70.0$} & $\mathrm{~T}=0.831$ & 0.408 \\
\hline Mean \pm SD & \multicolumn{2}{|c|}{$55.97 \pm 8.63$} & \multicolumn{2}{|c|}{$54.27 \pm 10.13$} & & \\
\hline
\end{tabular}


Table (2): Anthropometric measures of the participants

\begin{tabular}{|c|c|c|c|c|}
\hline & $\begin{array}{c}\text { Subjects } \\
(n=60)\end{array}$ & $\begin{array}{l}\text { Control } \\
(n=30)\end{array}$ & $\mathbf{t}$ & $p$ \\
\hline \multicolumn{5}{|l|}{ BMI $\left(\mathrm{kg} / \mathrm{m}^{2}\right)$} \\
\hline Min. - Max. & $23.88-44.08$ & $21.0-36.0$ & \multirow[t]{2}{*}{$4.810^{*}$} & \multirow[t]{2}{*}{$<0.001^{*}$} \\
\hline Mean \pm SD & $32.33 \pm 4.92$ & $27.21 \pm 4.42$ & & \\
\hline \multicolumn{5}{|c|}{ Waist circumference (cm) } \\
\hline Min. - Max. & $85.0-120.0$ & $90.0-116.0$ & \multirow{2}{*}{$3.159^{*}$} & \multirow{2}{*}{$0.002^{*}$} \\
\hline Mean \pm SD & $104.70 \pm 8.94$ & $98.13 \pm 9.99$ & & \\
\hline
\end{tabular}

Table (3) shows the glycemic profile and CRP levels for the two studied groups. Significant mean levels of FSG, HbA1c, serum insulin and HOMA-IR were found in diabetics $(164.07 \pm 56.08 \mathrm{mg} / \mathrm{dL}, 7.94 \pm 1.89 \%, 20.51 \pm$ $16.4 \mu / \mathrm{ml}, 7.70 \pm 6.0$ respectively) comparing to controls $(93.89 \pm 9.16 \mathrm{mg} / \mathrm{dL}, 5.39 \pm 0.44 \%, 8.94 \pm 4.04 \mu / \mathrm{ml}$, $2.03 \pm 0.91)$ were found, with levels being higher in diabetic subjects comparing to the controls. No statistical significance was found regarding the CRP levels in each group. The serum level of $25(\mathrm{OH})$ vitamin D3 was significantly lower in diabetics [ranged from 0.01 to $22.30 \mathrm{ng} / \mathrm{ml}$ with mean of $(2.91 \pm 4.20) \mathrm{ng} / \mathrm{ml}]$ comparing to controls [ranged from 2.10 to $26.9 \mathrm{ng} / \mathrm{ml}$ with mean of $(12.04 \pm 7.74) \mathrm{ng} / \mathrm{ml}](\mathrm{p}<0.001)$ (Figure 1). Additionally, a significant higher level of $25(\mathrm{OH})$ vitamin D3 was found in males comparing to female subjects (Figure 2).

Table (3): Glycemic profile and CRP levels of the participants

\begin{tabular}{|c|c|c|c|c|}
\hline & $\begin{array}{l}\text { Subjects } \\
(n=60)\end{array}$ & $\begin{array}{l}\text { Control } \\
(n=30)\end{array}$ & Test of sig. & $p$ \\
\hline \multicolumn{5}{|l|}{ FSG (mg/dL) } \\
\hline Min. - Max. & $92.0-378.0$ & $80.0-110.0$ & \multirow{2}{*}{$\mathrm{Z}=7.603^{*}$} & \multirow{2}{*}{$<0.001^{*}$} \\
\hline Mean \pm SD & $164.07 \pm 56.08$ & $93.89 \pm 9.16$ & & \\
\hline \multicolumn{5}{|l|}{$\mathbf{H b A}_{1} \mathbf{C}(\%)$} \\
\hline Min. - Max. & $5.20-13.50$ & $4.40-6.20$ & \multirow{2}{*}{$\mathrm{t}=9.930^{*}$} & \multirow{2}{*}{$<0.001^{*}$} \\
\hline Mean $\pm \mathrm{SD}$ & $7.94 \pm 1.89$ & $5.39 \pm 0.44$ & & \\
\hline \multicolumn{5}{|c|}{ Serum Insulin (u/ml) } \\
\hline Min. - Max. & $1.40-69.60$ & $1.50-16.0$ & \multirow{2}{*}{$\mathrm{Z}=4.007^{*}$} & \multirow{2}{*}{$<0.001^{*}$} \\
\hline Mean \pm SD. & $20.51 \pm 16.40$ & $8.94 \pm 4.04$ & & \\
\hline \multicolumn{5}{|l|}{ HOMA-IR } \\
\hline Min. - Max. & $0.77-24.0$ & $0.30-3.80$ & \multirow{2}{*}{$\mathrm{Z}=5.864^{*}$} & \multirow{2}{*}{$<0.001^{*}$} \\
\hline Mean $\pm \mathrm{SD}$ & $7.70-6.0$ & $2.03-0.91$ & & \\
\hline \multicolumn{5}{|l|}{ CRP } \\
\hline Min. - Max. & $1.0-118.0$ & $0.95 \pm 88.0$ & \multirow[t]{2}{*}{$Z=1.268$} & \multirow[t]{2}{*}{0.205} \\
\hline Mean \pm SD & $8.87 \pm 16.53$ & $14.82 \pm 23.80$ & & \\
\hline
\end{tabular}

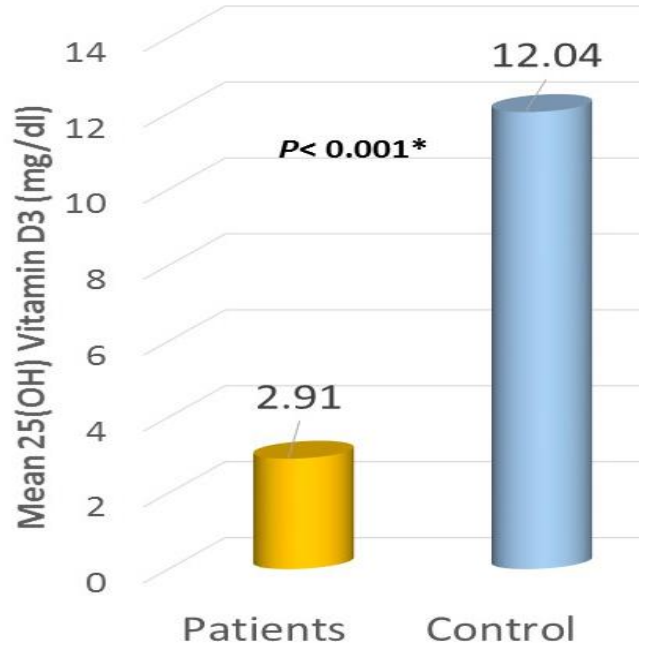

Figure (1): 25(OH) Vitamin D3 level of the participants

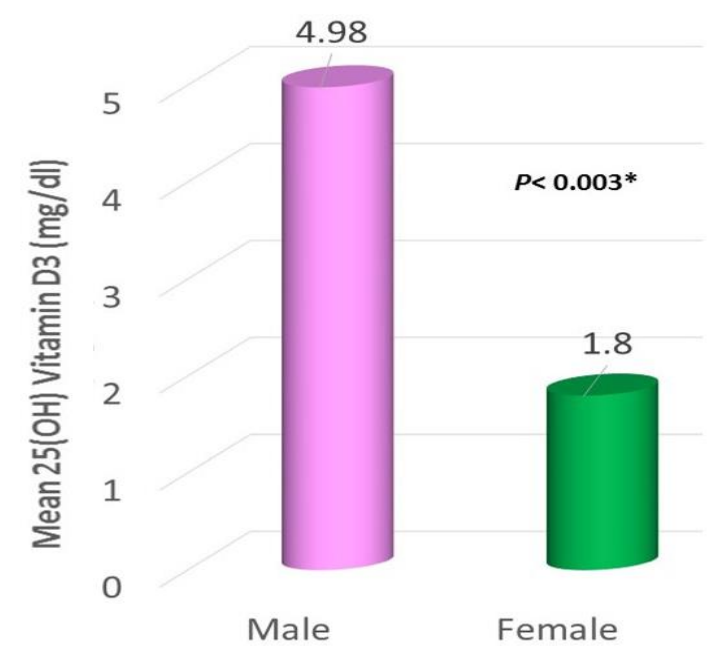

Figure (2): Relation between gender and 25(OH) Vitamin D3 in Subjects $(n=60)$ 
A statistical significant negative correlation was found between $25(\mathrm{OH})$ vitamin D3 level and the following parameters: BMI $(\mathrm{r}=-0.584, p<0.001)$, WC $(\mathrm{r}=-0.233$, $p=0.027)$, FSG ( $\mathrm{r}=-0.735, p<0.001), \mathrm{HbA1C}(\mathrm{r}=-0.387$, $p<0.001)$, HOMA-IR ( $\mathrm{r}=-0.729, p<0.001)$, and serum insulin $(\mathrm{r}=-0.272, p=0.010)$. No statistical significant correlation was found between $25(\mathrm{OH})$ vitamin $\mathrm{D} 3$ and CRP (r=-0.126, $p=0.238$ ) (Table 4).

Table (4): Correlation between 25(OH) vitamin D3 and different parameters

\begin{tabular}{|c|c|c|}
\hline & \multicolumn{2}{|c|}{$25(\mathrm{OH})$ Vitamin $\mathrm{D}_{3}$} \\
\hline & \multicolumn{2}{|c|}{ Total sample } \\
\hline & $\mathrm{r}_{\mathrm{s}}$ & $P$ \\
\hline Age (years) & -0.124 & 0.244 \\
\hline $\operatorname{BMI}\left(\mathrm{Kg} / \mathrm{m}^{2}\right)$ & $-0.584^{*}$ & $<0.001^{*}$ \\
\hline $\mathrm{WC}(\mathrm{cm})$ & $-0.233^{*}$ & $0.027^{*}$ \\
\hline Smoking index & 0.212 & 0.384 \\
\hline Systolic BP (mmHg) & -0.077 & 0.473 \\
\hline Diastolic BP (mmHg) & -0.199 & 0.060 \\
\hline Duration of DM (years) & 0.062 & 0.639 \\
\hline $\mathrm{FSG}(\mathrm{mg} / \mathrm{dL})$ & $-0.735^{*}$ & $<0.001^{*}$ \\
\hline $\mathrm{Hb} \mathrm{A}_{1} \mathrm{C}(\%)$ & $-0.387^{*}$ & $<0.001^{*}$ \\
\hline CRP & -0.126 & 0.238 \\
\hline Serum Insulin $(\mu / \mathrm{mL})$ & $-0.272^{*}$ & $0.010^{*}$ \\
\hline HOMA-IR & $-0.729^{*}$ & $<0.001^{*}$ \\
\hline
\end{tabular}

rs: Spearman coefficient

*: Statistically significant, $\mathrm{p} \leq 0.05$

\section{DISCUSSION}

The objective of this study was to assess serum $25(\mathrm{OH})$ vitamin D3 level in type 2 diabetic subjects and to examine its relation to glycemic control, proinflammatory markers and insulin resistance. The principal finding was that 25 $(\mathrm{OH})$ vitamin D3 level is significantly lower in type 2 diabetics than controls and the values in both groups were lower than the ideal level of $32 \mathrm{ng} / \mathrm{ml}$. In diabetic subjects $25(\mathrm{OH})$ vitamin D3 level ranged from 0.01 to $22.3 \mathrm{ng} / \mathrm{ml}$, while in controls it ranged from 2.1 to $26.9 \mathrm{ng} / \mathrm{ml}$. Our findings are comparable to those found in previous studies. ${ }^{(27-30)}$ Need et al., ${ }^{(31)}$ reported that the Subjects who had higher levels of Vitamin D concentration had lower FBS in comparison with the other groups. In contrast, other studies, did not trace any difference in $25(\mathrm{OH}) \mathrm{D}$ between subjects with diabetes comparing to normal population. ${ }^{32-}$ ${ }^{34)}$ Since the current study was conducted in Egypt, an area that receives adequate sunlight throughout the year, The high occurrence of vitamin D deficiency among participants encountered herein could be considered unexpected, and may be attributed to inadequate vitamin D intake which is prevalent around the world, regardless of the age or health status.

Significantly lower levels of $25(\mathrm{OH})$ vitamin D3 in females than in males in diabetic subjects was found in this study. A study done by, Verdoia, et al., (2015) ${ }^{(35)}$ supported this finding and concluded that gender significantly affects vitamin D status. Additionally, Takiishi et al., and van der Meer et al., ${ }^{(36,37)}$ suggested that female gender is an independent predictor of vitamin D deficiency. In the present study, vitamin D3 levels were found to be negatively correlated with FBG, HbA1c, serum insulin and HOMA-IR, indicating that vitamin D may be related to glycemic control in type $2 \mathrm{DM}$. This was consistent with a study done by Kostoglou-Athanassious et al., (2013) ${ }^{(38)}$ who concluded that there was a fairly strong correlation between vitamin $\mathrm{D}$ deficiency/insufficiency and type 2 $\mathrm{DM}$, and also demonstrates a negative correlation between vitamin D levels and HbA1c. Similarly, Clemente-Postigo, et al., $(2015)^{(29)}$ reported that serum $25(\mathrm{OH})$ vitamin D3 level was lower in prediabetic and diabetic subjects than in normoglycemic individuals and was found negatively correlated with glucose levels and HOMA-IR. In a crosssectional analysis of a general population sample in eastern Finland, an inverse association was observed between 25(OH)D3 levels and fasting insulin, fasting glucose and results of $2 \mathrm{~h}$ glucose tolerance test, suggesting that low serum $25(\mathrm{OH}) \mathrm{D} 3$ may be associated with impaired glucose metabolism. ${ }^{(39)}$ In another study, an inverse association of insulin resistance with $25(\mathrm{OH}) \mathrm{D} 3$ levels was observed which was mainly found at $25(\mathrm{OH}) \mathrm{D} 3$ levels between 16 and $36 \mathrm{ng} / \mathrm{ml}^{(40)}$

In Type $2 \mathrm{DM}$, the role of Vitamin D was suggested from the presence of Vitamin D receptors (VDR) on the pancreatic $\beta$-islet cells. ${ }^{(41)}$ Vitamin $D$ facilitates the production and secretion of insulin from pancreatic beta cells via its action on the VDR, thus appearing to regulate insulin secretion. ${ }^{(42)}$ Therefore vitamin D deficiency may be related to impaired insulin secretion in type $2 \mathrm{DM}$. In addition, as vitamin D stimulates the expression of the insulin receptor, vitamin D deficiency may be related with insulin resistance. ${ }^{(43)}$ Several studies demonstrated a relationship between single-nucleotide polymorphisms in 
the genes regulating VDR and Vitamin D binding protein and glucose intolerance and insulin secretion. ${ }^{(44-46)}$ The present study, concluded that there is a tight relation between type $2 \mathrm{DM}$ and obesity, where statistically significant increase in BMI and WC was found in type 2 diabetic Subjects comparing to control subjects. Among the studies consistent with our study are those done by Hertel, et al., $(2011)^{(47)}$ and Golay, et al., (2005) ${ }^{(48)}$ influenced by the presence of fat mass and obesity associated gene and these studies also concluded that obesity increases the resistance to insulin.

This study showed that there was a statistical significant negative correlation between BMI and $25(\mathrm{OH})$ vitamin D3 level. The association between serum vitamin D status and obesity can be explained in two ways; an appreciation was that obesity is a cause of vitamin D deficiency due to decreased sun exposure (as a result of lack of confidence in obese) and increased fat deposition, since vitamin D stored in adipose tissue becomes less bioavailable even with adequate sun exposure compared to non-obese. ${ }^{(49,50)}$ A potential confounder is that obesity is also linked to an unhealthier lifestyle, characterized by less physical activity, and poor eating habits and, hence, lower vitamin D levels and worse clinical outcomes. Bell, et al., (1985) ${ }^{(51)}$ stated that vitamin $\mathrm{D}$ can cause obesity, arguing that vitamin D deficiency is associated with secondary hyperparathyroidism stimulating 1 alpha hydroxylase activity leading to increase in $1,25(\mathrm{OH})_{2}$ vitamin $\mathrm{D}$, where both modulate $\mathrm{Ca}^{2+}$ signaling in adipocytes leading to stimulation of lipogenesis and inhibition of lipolysis.

A sensitive marker of low-grade inflammation, CRP is the most commonly measured marker of inflammation. ${ }^{(52)}$ Previous studies has demonstrated negative associations between CRP levels and vitamin D status. ${ }^{(53,54)}$ However, in the current study, there no significant correlation was found between CRP and vitamin D status. This finding is in consistent with a study done by Grossmann et al., (2015) $)^{(55)}$ who concluded that the inflammatory and immune biomarker profile including white blood cells (WBCs), granulocytes, lymphocytes, monocytes, platelets, CRP, albumin, fibrinogen, and hematocrit concentrations varies with the development and progression of type $2 \mathrm{DM}$. Markers of inflammation and immunity enable differentiation between the early preclinical and clinical phases of the disease, disease complications, and progression.

\section{CONCLUSION AND RECOMMENDATIONS}

In conclusion, the present study demonstrated that $25(\mathrm{OH})$ vitamin D3 level was significantly lower in subjects with type $2 \mathrm{DM}$ comparing to healthy normal controls in a sample of Egyptian population and was found to be negatively correlated with HOMA-IR and serum insulin. This suggest that low levels of $25(\mathrm{OH})$ vitamin D3 could be considered a potential risk factor for the development of type $2 \mathrm{DM}$. $25(\mathrm{OH})$ vitamin D3 deficiency was not associated with increased markers of inflammation. Vitamin D levels were related to glycemic control in diabetic subjects, thus vitamin D supplementation could have a therapeutic potential in prevention and management of type 2 DM. Further studies on the benefit of including vitamin $\mathrm{D}$ supplements in treatment protocol of type $2 \mathrm{DM}$ are needed.

\section{Limitations of the study}

The study had some limitations; the sample size was small and the sunlight exposure of each individual varies on a daily basis.

Conflict of Interest: None to declare.

\section{REFERENCES}

1. American Diabetes Association. Standards of medical care in diabetes - 2015: abridged for primary care providers. Clin Diabetes. 2015;33(2):97-111.

2. World Health Organization (WHO). Prevention of diabetes mellitus: report of a WHO study group. Geneva: WHO; 1994.

3. WHO Expert Consultation. Appropriate body-mass index for Asian populations and its implications for policy and intervention strategies. Lancet 2004; 363(9403):157-63.

4. American Diabetes Association. Diagnosis and classification of diabetes mellitus. Diabetes Care 2010; 33(Suppl 1): S62-9.

5. Holick MF. Vitamin D: Importance in the prevention of cancers, type 1 diabetes, heart diseases, and osteoporosis. Am J Clin Nutr. 2004;79:362-71.

6. How JA, Hazewinkle HAW, Mol JA. Dietary vitamin D dependence of cat and dog due to inadequate cutaneous synthesis of vitamin D. Gen Comp Endocrinol. 1994; 96:12-8.

7. Liu PT, Stenger S, Li H, Wenzel L, Tan BH, Krutzik SR, et al. Toll-like receptor triggering of a vitamin Dmediated human antimicrobial response. Science. 2006;311(5768):1770-3.

8. Penna G, Amuchastegui S, Giarratana N, Daniel KC, Vulcano M, Sozzani S, et al. 1,25-Dihydroxyvitamin D3 selectively modulates tolerogenic properties in myeloid but not serumcytoid dendritic cells. J Immunol. 2007;178(1):145-53.

9. Kovalenko PL, Zhang Z, Cui M, Clinton SK, Fleet JC. 1,25 dihydroxy vitamin $\mathrm{D}$-mediated orchestration of anticancer, transcript-level effects in the immortalized, non-transformed prostate epithelial cell line, RWPE1. BMC Genomics. 2010; 11:26.

10. Kumagai T, Shih LY, Hughes SV, Desmond JC, O'Kelly $\mathrm{J}$, Hewison M, et al. 19-Nor-1,25(OH)2D2 (a novel, noncalcemic vitamin $\mathrm{D}$ analogue), combined with arsenic trioxide, has potent antitumor activity against myeloid leukemia. Cancer Res. 2005;15(65):2488-2497.

11. Zittermann A. Vitamin D and disease prevention with special reference to cardiovascular disease. Prog Biophys Mol Biol. 2006; 92:39-48.

12. Bland R, Markovic D, Hills CE, Hughes SV, Chan SL, Squires PE. Expression of 25-hydroxyvitamin D31alpha-hydroxylase in pancreatic islets. J Steroid Biochem Mol Biol. 2004;89-90:121-5.

13. Maestro B, Davila N, Carranza MC, Calle C. Identification of a Vitamin D response element in the human insulin receptor gene promoter .J Steroid Biochem Mol Biol. 2003;84(2-3):223-30.

14. Cheng Q, Li YC, Boucher BJ, Leung PS. A novel role for vitamin D: modulation of expression and function of the local renin-angiotensin system in mouse pancreatic islets. Diabetologia. 2011; 54:2077-81.

15. Hu FB, Meigs JB, Li TY, Rifai N, Manson JE. Inflammatory markers and risk of developing type 2 diabetes in women. Diabetes. 2004; 53:693-700.

16. Gibson RS. Principles of nutritional assessment. 2nd ed. Oxford: Oxford University Press; 2005. 
17. Wilson PW, Grundy SM. The metabolic syndrome: practical guide to origins and treatment: Part I. Circulation. 2003;108(12):1422-4

18. Nayak SS, Pattabiraman TN. A new colorimetric method for the estimation of glycosylated hemoglobin Clin Chim Acta. 1981;109(3):267-74.

19. Werner W, Rey HG, Wielinger H. On the properties of a new chromogen for blood glucose determination according to the GOD/POD method. Z Analyt Chem. 1970; 252:224-8.

20. Aksnes LA simplified high-performance liquidchromatographic method for determination of vitaminD3 in human serum. Scand. J Clin Lab Invest. 1992; 52:177-82.

21. Spigal AM, Carter-Su C, Taylor S, Kulkarani RN. Mechanisms of action of hormones that act at the cell surface. In: Melmed S, Polonsky KS, Larsen PR, Kronenberg HM (eds). Williams Textbook of endocrinology. 12thed. Philadelphia: Elsevier Saunders; 2011. 62-82.

22. Salven MJ. Vitamins and trace elements. In: McPherson RA, Matthew R. Pincus MR (eds). Henry's clinical diagnosis and management by laboratory methods. $22^{\text {nd }}$ ed. Philadelphia: Elsevier Saunders; 2011.417-28.

23. Tanabe N, Saito K, Yamada Y: Risk assessment by postchallenge serum glucose, insulin response ratio, and other indices of insulin resistance and/or secretion for predicting the development of type 2 diabetes. Inter Med. 2009; 48:401-9.

24. Kricka LJ, Phil D, Path FR, Park JY. Optical techniques. In: Burtis CA, Ashwood ER, Bruns DE (eds). Tietz Textbook of clinical chemistry and molecular diagnostics. $5^{\text {th }}$ ed. St. Louis, Missouri: Saunders; 2012. 233-56.

25. Anonymous. Immunoturbidimetry. Human 2007. Available from: http://www.human.de/data/pom_info only/2007 05 pom info only immunoturbidimetry. pdf.[Accessed On: 16 May, 2016].

26. Kirkpatrick LA, Feeney BC. A simple guide to IBM SPSS statistics for version 20.0. Student ed. Belmont, Calif.: Wadsworth, Cengage Learning; 2013.

27. Nikooyeh B, Neyestani TR, Tayebinejad N, Alavi-Majd $\mathrm{H}$, Shariatzadeh N, Kalayi A, et al. Daily intake of vitamin D- or calcium vitamin D-fortified Persian yogurt drink (doogh) attenuates diabetes-induced oxidative stress: evidence for antioxidative properties of vitamin D. J Hum Nutr Diet. 2014;27 Suppl 2:276-83.

28. Moreira TS, Hamadeh MJ. The role of vitamin D deficiency in the pathogenesis of type 2 diabetes mellitus. E Spen Eur E J Clin Nutr Metab. 2010;5:e155-e65.

29. Clemente-Postigo M, Muñoz-Garach A, Serrano M, Garrido-Sánchez L, Bernal-López MR, FernándezGarcía D, et al. Serum 25-hydroxyvitamin D and adipose tissue vitamin D receptor gene expression: relationship with obesity and type 2 diabetes. J Clin Endocrinol Metab 2015;100(4):e591-5.

30. Bayani MA, Akbari R, Banasaz B, Saeedi F, authors. Status of Vitamin-D in diabetic Subjects. Caspian J Intern Med. 2014; 5:40-2.

31. Need AG, O'Loughlin PD, Horowitz M, Nordin BE, authors. Relationship between fasting serum glucose, age, body mass index and serum 25 hydroxyvitamin $\mathrm{D}$ in postmenopausal women. Clin Endocrinol (Oxf). 2005; 62:738-41.

32. Kos E, Liszek MJ, Emanuele MA, Durazo-Arvizu R, Camacho P, authors. Effect of metformin therapy on Vitamin D and Vitamin B12 levels in Subjects with type 2 diabetes mellitus. Endocr Pract. 2012; 18:179-84.

33. Payne JF, Ray R, Watson DG, Delille C, Rimler E, Cleveland J, et al., authors. Vitamin D insufficiency in diabetic retinopathy. Endocr Pract. 2012; 18:185-93.
34. Sheth JJ, Shah A, Sheth FJ, Trivedi S, Lele M, Shah $\mathrm{N}$, et al. Does vitamin D play a significant role in type 2 diabetes? BMC Endocr Disord. 2015; 15:5.

35. Verdoia M, Schaffer A, Barbieri L, Di Giovine G, Marino P, Suryapranata H, et al. Novara Atherosclerosis Study Group (NAS). Nutr Metab Cardiovasc Dis. 2015;25(5):464-70.

36. Van der Meer IM, Middelkoop BJ, Boeke AJ, Lips P. Prevalence of vitamin D deficiency among Turkish, Moroccan, Indian and sub-Sahara African populations in Europe and their countries of origin: an overview. Osteoporos Int. 2011;22(4):1009-21.

37. Takiishi T, Gysemans C, Bouillon R, Mathieu C. Vitamin $\mathrm{D}$ and diabetes. Endocrinol Metab Clin North Am. 2010;39(2):419-46.

38. Kostoglou-Athanassiou I, Athanassiou P, Gkountouvas A, Kaldrymides P. Vitamin D and glycemic control in diabetes mellitus Type 2. Ther Adv Endocrinol Metab. 2013;4(4):122-8.

39. Hurskainen A, Virtanen J, Tuomainen $T$, Nurmi $T$, Voutilainen S. Association of serum 25-hydroxyvitamin $\mathrm{D}$ with type 2 diabetes and markers of insulin resistance in a general older population in Finland. Diabetes Metab Res Rev. 2012; 28:418-23.

40. Heaney R, French C, Nguyen S, Ferreira M, Baggerly L, Brunel L, et al. A novel approach localizes the association of vitamin $\mathrm{d}$ status with insulin resistance to one region of the 25-hydroxyvitamin D continuum. Adv Nutr. 2013; 4:303-10.

41. Holick MF. Diabetes and the Vitamin D connection. Curr Diab Rep. 2008; 8:393-8.

42. Bourlon P., Billaudel B. Faure-Dussert A. Influence of vitamin D3 deficiency and 1,25 dihydroxy vitamin D3 on de novo insulin biosynthesis in the islets of the rat endocrine pancreas. J Endocrinol. 1999; 160:87-95.

43. Talaei, A., Mohamadi, M. and Adgi, Z. The effect of vitamin $\mathrm{D}$ on insulin resistance in Subjects with type 2 diabetes. Diabetol Metab Syndr. 2013; 5:8.

44. Szathmary EJ. The effect of Gc genotype on fasting insulin level in Dogrib Indians. Hum Genet. 1987; 75:368-72.

45. Hirai M, Suzuki S, Hinokio Y, Hirai A, Chiba M, Akai $\mathrm{H}$, et al. Variations in Vitamin D-binding protein (groupspecific component protein) are associated with fasting serum insulin levels in Japanese with normal glucose tolerance. J Clin Endocrinol Metab. 2000; 85:1951-3.

46. Baier LJ, Dobberfuhl AM, Pratley RE, Hanson RL, Bogardus C. Variations in the Vitamin D-binding protein (Gc locus) are associated with oral glucose tolerance in nondiabetic Pima Indians. J Clin Endocrinol Metab. 1998; 83:2993-6.

47. Hertel JK, Johansson S, Sonestedt E, Jonsson A, Lie RT, Platou CG, et al. FTO, type 2 diabetes, and weight gain throughout adult life: a meta-analysis of 41,504 subjects from the Scandinavian HUNT, MDC, and MPP studies. Diabetes. 2011;60(5):1637-44.

48. Golay A, Ybarra J. Link between obesity and type 2 diabetes. Best Pract Res Clin Endocrinol Metab. 2005;19(4):649-6.

49. Zhang M, Li P, Zhu Y, Chang H, Wang X, Liu W, et al. Higher visceral fat area increases the risk of vitamin $\mathrm{D}$ insufficiency and deficiency in Chinese adults. Nutr Metab (Lond). 2015; 12:50.

50. Wortsman J, Matsuoka LY, Chen TC, Lu Z, Holick MF. Decreased bioavailability of vitamin $D$ in obesity. Am J Clin Nutr. 2000;72(3):690-3.

51. Bell NH, Espin S, Greene A, Shary J, Oexmann MJ, Shaw S. Evidence for alteration of vitamin D endocrine system in obese subjects. J Clin Invest 1985; 76: 370-3.

52. Mirza S, Hossain M, Mathews C, Martinez P, Pino P, Gay JL, et al. Type 2-diabetes is associated with elevated 
levels of TNF-alpha, IL-6 and adiponectin and low levels of leptin in a population of Mexican Americans: a crosssectional study. Cytokine. 2012; 57:136-42.

53. Targher G, Bertolini L, Padovani R, Zenari L, Scala L, Cigolini M, et al. Serum 25-hydroxyvitamin D3 concentrations and carotid artery intima-media thickness among type 2 diabetic Subjects. Clin Endocrinol (Oxf). 2006; 65:593-7.

54. Eleftheriadis T, Antoniadi G, Liakopoulos V, Stefanidis I, Galaktidou G. Inverse association of serum 25- hydroxyvitamin D with markers of inflammation and suppression of osteoclastic activity in hemodialysis Subjects. Iran J Kidney Dis. 2012; 6:129-35.

55. Grossmann V, Schmitt VH, Zeller T, Panova-Noeva M, Schulz A, Laubert-Reh D, et al. Profile of the immune and inflammatory response in individuals with prediabetes and type 2 diabetes. Diabetes Care. 2015; 38(7):1356-64. 